\title{
DISCRIMINATION, ASSIMILATION, and CULTURAL IDENTITY in TAHAR BEN JELLOUN'S LEAVING TANGIER
}

\author{
Derya Emir \\ Dumlupinar University, Western Languages and Literature Department \\ derya_emir@hotmail.com
}

\begin{abstract}
In today's multicultural countries, cultural diversity, hybridity, assimilation, and cultural identity are key issues. By focusing on the problem of immigration and its inevitable traumatic results on the migrants, Tahar Ben Jelloun's Leaving Tangier fully presents Azel (the protagonist) and his acquaintances' search for identity in terms of history, religion, nationality and cultural identity. Tahar Ben Jelloun's Leaving Tangier is the story of a Moroccan brother and sister who are burning with the desire to migrate to Spain in order to attain better life. The accomplishment of their dreams actualizes at the cost of some compromises and sacrifices that end with the protagonists' physical, emotional failure, and annihilation. The winner of Prix Goncourt for La Nuit Sacrée (The Sacred Night) in 1987, a Moroccan novelist Tahar Ben Jelloun is one of the most prolific and important writers of the recent years. As a novelist and critic, Ben Jelloun arffully combines the fact and fiction, past and present, East and West in his works. in this respect, he creates multidimensional writings that can be read and interpreted from several perspectives. Tahar Ben Jelloun's Leaving Tangier (2006) presents the issues of "wounded childhood," "solitude," "displacement," and "alienation" both individually and collectively in the colonial history of Tangier. This study focuses on the issues of discrimination, assimilation, and cultural identity, experienced by the characters in the novel, resulting from the immigration of individuals from their homelands to Europe in order to find better life conditions.
\end{abstract}

Key Words: Discrimination, Assimilation, Immigration, Cultural identity, Tahar Ben Jelloun, Leaving Tangier, Postcolonial Literature.

\section{Introduction}

In today's multicultural countries, the issues such as immigration, assimilation, and confusion of cultural identity are well known discursive concepts. By depicting the relations between Morocco and Spain, Tahar Ben Jelloun's most recent novel, Leaving Tangier, presents a critical point of view on migration and intercultural exchanges between Morocco and Spain in this framework.

Tahar Ben Jelloun is a well-known Moroccan poet, novelist, and short story writer. Published originally in French as Partir, Leaving Tangier is Ben Jelloun's thirteenth novel. in 1987, Ben Jelloun "became the first Arab writer to win France's most prestigious literary prize when his novel La Nuit Sacrée was awarded the Prix Goncourt." (Rifaat, 1991). in his works, he artfully combines fact and fiction, past and present, East and West and creates multidimensional writings that can be read and interpreted from several perspectives. Leaving Tangier focuses on the problem of immigration and its inevitable consequences on the migrants. The novel presents Azel (the protagonist) and his acquaintances' search for identity in terms of sexual oppression, religion, values, nationality and class struggle. in the novel, the issues such as "wounded childhood," "solitude," "displacement," and "alienation" are narrated as experienced by the characters both individually and collectively in the colonial history of Tangier. This study focuses on the issues of discrimination, assimilation, and cultural identity resulting from the immigration of individuals from their homelands to Europe in order to find better life and chances by referring Ben Jelloun's Leaving Tangier.

Born in Fez, Morocco, in 1944, Tahar Ben Jelloun, at the age of five, "was enrolled in a Koranic school, where he learned to memorize and recite verses from the Koran. Two years later, he entered a Franco-Arab school, studying French in the morning and Arabic in the afternoon. [...] in 1971, at the age of twenty-six, Ben Jelloun immigrated to France to complete his studies at the Sorbonne" (Ben Jelloun \& Guppy, 1999).

Published his first novel, Harrouda, in 1973, Tahar Ben Jelloun is the recipient of several prizes, including the Prix de l'Amitie Franco-Arabe for in 1976, the Prix Goncourt in 1987, and the Prix Maghreb in 1994. He is "one of France's most celebrated writers" (Ben Jelloun \& Guppy, 1999) and his writings "emanate from very real and concrete situations and position him clearly as a postcolonial author on both sides of the Mediterranean, in the Maghreb and in France" (Parekh \& Jagne, 1998). Ben Jelloun's personal, political and intellectual experiences also contributed to his development as a 
ISSN 2411-9563 (Print) ISSN 2312-8429 (Online)
European Journal of Social Sciences Education and Research
September-December 2014

Volume 1, Issue 2

postcolonial author; he spoke out "injustice, racism, indifference, economic oppression, hypocrisy, torture" (Parekh \& Jagne, 1998). Due to his Arab/lslamic heritage, Ben Jelloun's identity and the medium of expression in his fiction have been questioned much both in France and Maghreb. He is a Maghrebian Francophone writer, and in one of his interviews, Ben Jelloun, in response to the interviewer's query about the use of French as the medium of expression in his fiction, replied that

I belong to a specific category of writers, those who speak and write in a language different from that of their parents. I am a Moroccan, an Arab. My culture is Arab, Islamic, but it was in French, the language of the former colonial power, that I spontaneously expressed myself when I began to write. This is a paradox which stems from a historical situation. [...] I don't feel guilty about expressing myself in French; nor do I feel that I am continuing the work of the colonizers. Actually, what I express in French could very well be expressed in any other language. [...] in a sense, we Arab writers who write in French are the ones who offer hospitality to the French language! Not only do we adopt it, we invite it home, we transform it, we take it to places where it is not accustomed to go. (Ben Jelloun, 1991)

\section{DISCRIMINATION, ASSIMILATION, and CULTURAL IDENTITY in TAHAR BEN JELLOUN'S LEAVING TANGIER}

The issues of migration and its traumatic results on the migrants have been debated much in multicultural societies. Although immigrants are generally seen as potential threats to the national unity and cohesion, the effects of immigration on the immigrants regarding the constitution of cultural identity, assimilation, and adaptation to a new country have been serious issues that attracted to scholarly studies. Leaving Tangier presents the distressing story of Moroccan characters that endeavor to migrate from Tangier to Spain in order to attain better life conditions. in one of his interviews, Ben Jelloun states that "for an immigrant, life is very different. He is a symbol of the human condition unloved, not recognized, a condition that places each human being at the level of his ability to work. [...] My novel Leaving Tangier has a message for the young: Immigration is not a pleasure trip; it is not a fun weekend; it is hard and difficult, because there is racism, humiliation, and Ioneliness" (Ben Jelloun, 2014). in the novel, regarding their ethic and cultural identity, racial and religious problems in the new country, the migrant characters' dreams turn into nightmares on the way of immigration to achieve a better life.

Throughout the novel, leaving Tangier keeps the characters so busy that they actually lose both their North African and newly gained European identities; they can neither settle nor survive in both of the lands. They are pushed to their fatalistic solitude because of the exclusion of the West; their humanity and physical beings are belittled and humiliated. Regarding the novel and its characters, the novelist states that "this novel was widely read and discussed in Morocco, where I introduced it upon its release. Leaving Tangier was well received in countries very different from Morocco, [...]. This is a novel that I rewrote three times by changing the construction. I worked a lot, because I wanted to reach a level where any reader from any country can identify with one of my characters. [...] I like my characters, because I identify with each one and put myself in his skin like an actor" (Ben Jelloun, 2014).

Located at the northern tip of Morocco, Tangier is a port and a border town. Regarding the colonial history of Tangier, Melvin E. Page states that Until 1956, Tangier had the status of an international city. Although it had a representative of the royal authority, the city was administered by several different countries: France, Spain, England. After World War II, democratic and nationalist Moroccan parties made claims for independence, which was achieved in 1956. Independent Morocco obtained the Spanish colony of Ifni and began making claims to Western Sahara, Ceuta, Melilla, Mauritania, although making these claims was primarily a strategy to divert attention from internal social, political, and economic problems. (Page \& Sonnenburg, 2003)

The novel opens with the Café Hafa which is located in Tangier with a view of Straits of Gibraltar. The narrator describes the thoughts and actions of the young Moroccans who are sitting at the Café Hafa. The sitters gather at the Café and gaze admiringly the glimmering lights of the Spanish coast. They all share the same dream: to quit Tangier and move to the other side of the Mediterranean coast that promises better life conditions and chances for them:

the Café Hafa becomes an observatory for their dreams and their aftermath. Long pipes of kif pass from table to table while glasses of mint tea grow cold, and enticing bees that eventually tumble in, a matter of indifference to customers long since lost to the limbo of hashish and tinseled reverie. in the back of one room, two men meticulously prepare the key that opens the gates of departure, selecting leaves, then chopping them swiftly and efficiently. (Ben Jelloun, 2009)

What brings the young Moroccans at the Café Hafa together is to reach the same goal: to land the Spanish shores of Tarifa in order to obtain better life conditions. The novel presents "how poverty, corruption and the lack of employment fuel dreams of leaving Tangier" (Nice, 2009). Azel is the protagonist of the novel and is surrounded by the same feeling of departure 
ISSN 2411-9563 (Print) ISSN 2312-8429 (Online)
European Journal of Social Sciences Education and Research
September-December 2014

Volume 1, Issue 2

from his homeland to arrive Spanish shores. He is an inventive, talented but an unemployed boy despite his law degree. Azel is fascinated by the feeling of leaving Tangier and burns within the desire of leaping the other side of the Mediterranean passionately: "the idea of sailing away, of mounting a green-painted horse and the crossing the sea of the straits, that idea of becoming a transparent shadow visible only by day, an image scudding at top speed across the waves - that idea never leaves him now" (Ben Jelloun, 2009). Azel believes that he is able to achieve the opportunities in the dream land that he has already failed to catch in his own land:

Leaving the country. It was an obsession, a kind of madness that ate him day and night: how he could get out, how could he escape this humiliation? Leaving, abandoning this land that wants nothing more to do with his children, turning your back on such a beautiful country to return one day, proudly, perhaps as a rich man: leaving to save your life, even as you risk losing it [...]. (Ben Jelloun, 2009)

While watching the shores of Spain, the survivors of the Café Hafa call the sea "Toutia" which would carry them from homeland to the dream land. Toutia has an ambivalent nature and this ambivalence is explained by the narrator as: "she is a spider that can feast on human flesh yet will sometimes warn them, in the guise of a beneficent voice that tonight is not the night, which they must put off their voyage for a while" (Ben Jelloun, 2009). From the quotation, Toutia sometimes swallows the bodies of unlucky dreamers and sends their dead bodies back to shore. Toutia also warns "them to postpone their voyage when the night is not good enough for departure" (Pireddu, 2009).

While the individuals are sitting at the Café, they are sipping mint tea around which the bees are flying and dropping in the glasses. The narrator makes an analogy between the fates of the bees, which are drowned in the dreamers' big glasses full of mint tea and the dreamers' positions, who are watching the monstrous waves of Toutia. in this respect, the positions of the dead bees foreshadow the fate of the dreamers who are burning with the desire of leaving their countries for a better life. The analogy between the bees and the dreamers is narrated as follows:

In the tall glasses of cold tea, the green mint has been tarnished black. The bees have all drowned at the bottom. The men no longer sip this tea now steeped into bitterness. With a spoon they fish the bees one by one, placing them on the table and exclaiming, "Poor little drowned things, victims of their own greediness". (Ben Jelloun, 2009)

Azel is one of the dreamers among the young Moroccans sitting at the Café Hafa. He thinks that landing on Europe will provide him a chance for freedom, but he becomes a kind of victim in the service of Miguel both sexually and emotionally. Azel is living with his mother, Lalla Zohra, and his sister, Kenza. Although he studied law, he is an unemployed young Moroccan man yearning for leaping to the other side of the Mediterranean to acquire a better life. Azel's innocence and inexperience is narrated thus:

Poor Azel, he never had a chance to live, did everything he could to break free - just think, if he'd managed to set out for Spain, by now he'd be a brilliant lawyer or a university professor. [...] a victim of unemployment, of a carelessly negligent system - such a bright boy, well educated, sensitive, warmhearted, what a pity that he got on that damned bus with those bald tires, [...]. (Ben Jelloun, 2009)

Due to its historical and cultural richness, Tangier has been an international city including Muslim, Christian, and Jewish communities. Morocco was exposed to the colonization of many Western countries and the country gained its independence in 1956. Regarding the multicultural status of Tangier, Ben Jelloun notes that

for some forty years, until 1957, Tangier had the status of an international city. [...] Although it had a representative of the royal authority, the city was administered by several different countries. However, the most widely spoken language, apart from Arabic, was Spanish, [...]. There were as many schools as there were countries represented in the city. Young Moroccans had the choice between the Spanish Institute and the Italian school, the American school and the French lycee. At this time cosmopolitanism was a lifestyle, multi-lingualism was not encumbered by the problem of identity, and the Muslims of Tangier lived in the same neighbourhoods as the Christians and the Jews. The Calle Sevilla was known as the Spaniards' street, but Muslims lived in the same buildings side-by-side with the Spaniards and there was no feeling of mistrust between the two. It was a time when Moroccans wondered how nearby Spain, a fairly poor country, could be capable of colonizing them. (Ben Jelloun, 1997)

Although the country gained independence, the indigenous peoples were exposed to Western degradation and exploitation continuously. Regarding the constant influence of Western colonization on the country, the former King Hassan II states that "Morocco is like a tree whose roots are in Africa but whose leaves are moved by the wind of Europe" (Antonio Azbitarte, interview on 18 May, 2013). Situated in the northern tip of the country, Tangier's geographical position was important 
because the city was a meeting place for multiple identities, cultures, and traditions. Regarding the strategic position of Tangier, Michael K. Walonen observes that

This colonial presence took on a particularly forceful and idiosyncratic form in Tangier, which had a unique political status, population demographic, and also (and hence) spatiality. Since the nineteenth century an international administration had been in place in Tangier [...]. A longtime center for diplomatic relations between Morocco and the nations of Europe, Tangier had for some time been home to an eclectic international population; a port city and a border town on the frontier of a more wealthy region to the north, Tangier had also for some time had its fair share of sex work and trade of contraband goods. As the era of the International Zone moved along, the city's status as an economic free zone attracted a large number of financial speculators and the idle rich, but intertwined with this, the zone's climate of moral permissiveness and the access it afforded to commercial sex, particularly of the homosexual variety, attracted an expatriate population looking to free itself from the moral restrictions of its native lands. (Walonen, 2011)

Due to its geographic position - the city has a large international port - Tangier attracted and hosted many immigrants and writers such as Paul Bowles, William S. Burroughs, Jean Genet, Mohamed Choukri who all stayed permanently or visited Tangier during different periods of the twentieth century. Among these writers, Paul Bowles, an expatriate American writer, was the one who spent nearly half a century living and writing in Tangier. Neil Campbell quotes one of Bowles's impressions about Tangier as follows:

mixture of cultures, where you might run into a Polish refugee [...] an American construction worker [...] a tailor from Rome and where the past and the present exist simultaneously in proportionate degree, where a very much alive today is given an added depth of reality by the presence of an equally alive yesterday. (Campbell, 2000)

Regarding Tangier's position as a meeting place of multiple identities, cultures, and traditions, Paul Bowles also claimed that Tangier was "an enormous market where goods, information, and people were bought and sold [...] unloaded and reloaded [...] without valid documents to identify them" (Bowles, cited in Campbell, 2000). Bowles' quotation reflects a colonizer's perspective which regards Tangier as an enormous market in which people (young naive Moroccans) can be bought and sold like "cabbages or carpets" (Brandabur, 2010). His quote also presents the hopeless situation of the young Moroccans whose identities and individualities are disregarded by the colonizers. in the novel, Ben Jelloun makes reference to Paul Bowles: "an American writer and his wife lived in an apartment building" in Tangier (Ben Jelloun, 2009), who see young Moroccan people as a kind of material to enhance the creativity of their writings. Ben Jelloun depicts the abused positions of the indigenous Moroccans and their exploitation by the Westerners as follows:

That type, they want everything, men and women from the common people, young ones, healthy, preferably from the countryside, who can't read or write, serving them all day, then servicing them at night. A package deal, and between two pokes, tokes on a nicely packed pipe of kif to help the American write! Tell me your story, he says to them, I'll make a novel out of it, you will even have your name on the cover: You won't be able to read it but no matter, [...]. That's what he tells them, without mentioning money [...]. They aren't obliged to accept, but I know that poverty - our friend poverty - can lead us to some very sad places. People have to make do with life, that's how it is, and me, I see everything, but I don't say everything. (Ben Jelloun, 2009)

As seen in the quotation above, the local Moroccans are in a desperate position due to the country's colonial history. Although the novel depicts the post-colonial period of Tangier, the young Moroccans endeavor to leave Tangier in order to avoid poverty and suffering. Due to the radical differences between the European culture and traditions and those of theirs, the characters experience ambivalent and conflicting ideas. Despite of his conflicting ideas, Azel is eventually able to leave Morocco by the help of a wealthy Spanish man named Miguel. The encounter between Azel and Miguel happens purely by chance. Miguel López is "an elegant man who dressed with exquisite taste. [...] He spends the summer in Tangier and the rest of the year in Barcelona [...]. A generous man, he has a passion for Morocco because of the quality of life there, its infinite variety" (Ben Jelloun, 2009). Just before his departure, Azel writes a letter expressing his feelings and passions for Europe. The letter, as opposed to the latter one, expresses Azel's enthusiasm, excitement, and joy for Spain. By addressing his own land as "Dear country," Azel states that

I finally have the opportunity and good fortune to go away, to leave you, to breathe the air of a new country, to escape the harassment and humiliations of your police. I set out, my heart light, eyes fixed on the horizon, gazing into the future, unsure of what I will do - all I know is that I'm ready to change, ready to live free, to be useful [...]. I am not leaving you forever. 0 my country, my thwarted will, my frustrated desire, my chief regret! You keep with you my mother, my sister, and a few friends: you are my sunshine and my sadness: I entrust them to you because I will return [...]. (Ben Jelloun, 2009) 
ISSN 2411-9563 (Print) ISSN 2312-8429 (Online)
European Journal of Social Sciences Education and Research
September-December 2014

Volume 1, Issue 2

By the help of Miguel, "who is a rich homosexual art dealer and viveur who rescues him from a police dragnet and ultimately gives him a chance to quit his country, Azel can board a plane with a regular visa application instead of risking an arrest or even his life on an illegal trafficker's boat, and finally lands on the European soil" (Pireddu, 2009). Miguel is a homosexual man: "whenever Miguel forced a man to become involved with him, he regretted it, but he found a kind of perverse pleasure in feeling lonely and sorry for himself. [...] He loved the "awkwardness" of Moroccan men, [...]. He loved the oil sheen of their skin. and he loved their availability, which marked an inequality in which the relationship was formed, [...]" (Ben Jelloun, 2009). As seen in the quotation, Miguel's perception of the young Moroccans reflects the colonizer's vision which disregards the native's individuality and humanity. As Edward Said puts it, in the mind of the West, Arabs are "shown to be gullible, "devoid of energy and initiative," much given to "fulsome flattery," intrigue, cunning, and unkindness to animals; Orientals cannot walk on either a road or a pavement (their disordered minds fail to understand what the clever European grasps immediately, that roads and pavements are made for walking); and Orientals are inveterate liars, they are "lethargic and suspicious," [...]" (Said, 1979). Accordingly, Azel is a colonized man and is always in the need of attention of the West in order to materialize his dreams. So, by the help of Miguel - the protective, benevolent, and masculine - Azel, who is depicted as weak, outsider, and feminine, could actualize his dreams. However, as the time passes, Azel is torn by his dreams and the actual nature of external reality. He lives dilemmas because he realizes the complexity between his Moroccan identity and Spanish culture. Lying in the bed in his little room, Azel once again addresses his own country with a letter. As opposed to the previous one, this letter highlights the opposition between the two coasts of the Mediterranean and includes Azel's yearning, regret, and longings:

Here I am, far from you, and already I miss something of you [...]. You know from Morocco you can see Spain, but it doesn't work like that in the opposite direction. The Spanish do not see us, they don't give a damn, they've no use for our country. I'm in my little room [...]. I'll try to fall asleep thinking of you, my dear country, dearest and the greatest of my anxieties." (Ben Jelloun, 2009)

Captured by the conflicting ideas, Azel's disappointment and loneliness reach climax when Miguel forces him to wear women's clothes for a party that he holds for his guests: Miguel "had invited some thirty people for a disguise party with the theme of "The Orient: Think Pink!" (Ben Jelloun, 2009). While Miguel dresses a vizier of the Arabian Nights, Azel is forced to "wear a caftan, a wig that was almost red, a belt embroidered with gold, babouches, and a veil. Nothing but women's clothes! Azel realized immediately what Miguel had in mind. [...] Miguel whispered in Azel's ear, 'you're going to dance. and you'll dance like a whore.' [...] He began to dance to some Egyptian music, moving his buttocks [...]' (Ben Jelloun, 2009). This scene indicates the abused and humiliated position of the natives at the merciless hands of the colonizers. Azel becomes the "Other" and his humanity and identity are belittled and degraded by Miguel's capricious manners. in this respect, the hospitality of the West is transformed into a kind of ethnocentrism by Miguel. Although Azel is offered job, luxurious clothes and a safe life by his benefactor, an uncompromising gap occurs between his Moroccan roots and the newly adopted Europeanness. Pireddu observes that "Azel's increasing distress for his sexual duplicity, weakening, and confusion caused by his relationship with Miguel is the symptom of a greater ambivalence and crisis common to most allegedly Europeanized immigrants in the novel" (Pireddu, 2009).

Azel gradually "abandons all thoughts of gratefulness to Miguel for granting him the opportunity to cross the Mediterranean" (Pireddu, 2009). He soon learns that day-dreams can be misleading. As the time passes, he realizes his own complexity that pushes him into condemnation. He begins to feel antagonism toward the country and its culture that he has immigrated. He blames Miguel and Spain because he thinks that they are guilty for creating all the problems.

In the novel, dreaming and departure are keywords that obsessively capture mind of the characters. Like Azel, Siham is another character "who yearns no less than Aziz's family members to migrate to the closest piece of Europe" (Pireddu, 2009). Siham is Azel's girlfriend and she is provided an employment in Marbella by El Haj. Although she is inexperienced and isn't being trained for nursing, Siham has to look after a disabled girl, named Widad. Although Tangier is depicted as a city that is incapable to grant security and comfortable life for its residents, El Haj expresses the temptation of Tangier that binds its people together with the feeling of yearning:

Don't go crazy, my dear, you'll see: even if you leave, you'll always miss your country. We become so attached to Morocco that we can't forget it completely, it really sticks to us, like an unseasoned frying pan, and we can't forget it. I travelled quite a bit in my youth, thanks to easy money and parents who never asked questions. I went far away and wherever I was, strangely enough I missed Morocco. (Ben Jelloun, 2009) 
ISSN 2411-9563 (Print) ISSN 2312-8429 (Online)
European Journal of Social Sciences Education and Research
September-December 2014

Volume 1, Issue 2

Despite El Haj's emotional speech, for Siham "the chances offered by her four-month European visa are a sufficiently good incentive to put up with the emotional distress of her current job situation in Spain rather than falling prey to the compromises to which women have to stoop in her home country in order to survive" (Pireddu, 2009).

In the novel, Malika is another character who burns with the desire of leaving her home land for Spain. Fourteen years old Malika is Azel's neighbor and she is forced to leave the school to work for a Dutch factory where "she sorely missed her days at school and her little forays of escape to the Terrasse des Paresseux to look at the sea" (Ben Jelloun, 2009). Like the other characters, she enjoys watching the boats for a long time coming and going and she dreams of herself in a "boat to Algeciras or Tarifa, disembark in Spain, and find a job there. She would be saleswoman, or a hairdresser, or maybe a model" (Ben Jelloun, 2009). This is how the third person narrator expresses the fragmented and traumatic position of the natives who works for the European market:

Like her girlfriend Achoucha, the neighbor lady Hafsa, her cousin Fatima, and hundreds of girls in her neighborhood, Malika went off to shell shrimps in the Dutch factory down in the free zone of the port. Every day refrigerated trucks brought in tons of cooked shrimps, caught in Thailand and shipped through the Netherlands, where they were treated with preservatives. in the factory, small hands with slender fingers shelled them day and night, after which the shrimps travelled to yet another destination to be canned before debuting at last on the European markets. in Tangier, the girls were paid a pittance. Even with the best will in the world, only a very few were able to process more than ten pounds. (Ben Jelloun, 2009)

Exhausted by working for the Dutch company, Malika falls fatally ill. When she is taken to hospital, the doctor exclaims "another victim of those shrimp!" (Ben Jelloun, 2009). Malika's dreams are so powerful that it "wasn't the examination that frightened her, it was dying - leaving without realizing her dream, leaving without ever having left the country, leaving to be buried in a hole in the cold, cold ground" (Ben Jelloun, 2009). Malika becomes gravely ill and she knows that death is waiting for her out in the corridor; she feels the smell of death everywhere in the hospital room. Because of the effects of the medicines, Malika always of dreams at the hospital; she dreams of herself leaving her home country with a passport in her hand:

If only I were in France, I wouldn't be in a hospital - simply because I wouldn't be sick, because I wouldn't have been working in a freezing factory, I wouldn't have caught this lung disease, [...]. I should have left, I should have held on to Azel's hand and never let go, [...] he would never have abandoned me. [...] My mother told me the other day that Azz El Arab's sister has gone to Spain; even her mother, it seems, is about to go rejoin her son and daughter. They are so lucky! (Ben Jelloun, 2009)

Malika's excessive desire to leave Morocco comes true only by her tragic death. Without fulfilling the European dream in her real life, she succeeds in abandoning her Moroccan existence during her premature death: "Malika stopped screaming. It is in eternal silence that quits the country. She has finally left. Forever" (Ben Jelloun, 2009).

Leaving Tangier narrates the tragedy of the migrants who "turn into paradoxical non-existing human beings" (Pireddu, 2009) because of their estrangement both from their Moroccan roots and from their newly acquired Europeanism. They are "condemned to invisibility by their foreignness even when they are socially and juridically legitimized" (Pireddu, 20009) in Europe. Kenza, Azel's sister, soon joins to the other migrant characters in order to improve her life. Working as a nurse at a hospital in Tangier, Kenza spends her life waiting for "true love, real, sincere, overwhelming love, and for once, just once, to experience those sublime moments described so tellingly in the films and novels she had adored" (Ben Jelloun, 2009). Her mother, Lalla Zohra, forces her to find a handsome husband with fine financial prospects; however, Kenza is quite sure that it is impossible to find such a husband and love in Morocco "not because Moroccan men were incapable of such emotion, but because daily life and public opinion would always stifle true love in the end" (Ben Jelloun, 2009). Like Azel, Kenza's migration is provided by Miguel who agrees to marry Kenza in order to provide her Spanish citizenship. Before her dream of leaving occurs, Miguel converts into Islam and takes the name of Mounir. Eventually, she safely arrives in Spain by the help of Miguel who welcomes her like a princess in Barcelona. She becomes Miguel's wife on paper. During her stay in Spain, Kenza enjoys her freedom working as a dancer and soon meets a Turkish man, Nazım. However, Kenza's hopes and desires to find happiness in the adoptive European home soon fail due to her relation with Nazım. Nazım betrays Kenza and she falls in to a deep misery and desperation which lead her to commit suicide. Her shattered dreams and nostalgia for the dream land are acknowledged by Miguel ironically toward the end of the novel. Behaving just as a pragmatic colonial, Miguel decides to send Azel and Kenza back to their homeland because he profits them utmost and annihilates them both physically and emotionally: 
ISSN 2411-9563 (Print) ISSN 2312-8429 (Online)
European Journal of Social Sciences Education and Research
September-December 2014

Volume 1, Issue 2

Miguel now realized that there was something terrifying about loneliness of immigration, a kind of descent into a void, a tunnel of shadows that warped reality. Kenza had let herself be caught in the maze, and Azel, well, he had gone desperately wrong. Exile revealed the true dimensions of calamity. (Ben Jelloun, 2009)

For both Kenza and Azel, the life in Spain does not correspond to their ambitions, desires and hopes. Both of them are annihilated and corrupted sexually, individually and morally in the dream land. Due to her nostalgia for homeland and her disappointments, Kenza gets the chance to return for homeland on hearing the death of the despotic King Hassan II: "it was then that Kenza felt the hour had come for her to go home at least to Morocco". (Ben Jelloun, 2009). However, Azel pursues staying in Spain because "there was only one thing he didn't want: to be sent back to Morocco. The shame, the hchouma, and the hegra, the humiliation - no, never, anything but that [...] He had left. Left to return only like a prince, not like garbage tossed out by the Spanish." (Ben Jelloun, 2009). Pireddu states that "despite wrong choices and broken reveries, Azel, now a secret informer for the Spanish police fighting against the terrorism that threatens Europe, still dreams of returning to Morocco like a hero and of appearing on TV" (Pireddu, 2009). According to Pireddu "Azel's increasing distress for his sexual duplicity, weakening, and confusion caused by his relationship with Miguel is the symptom of a greater ambivalence and crisis common to most allegedly Europeanized immigrants in the novel"(Pireddu, 2009). Azel's dreams, hopes, and desire for Europe tragically end with his violent death at the end of the novel: "Azel was on the floor, his throat cut, his head in a pool of blood. The Brothers had slaughtered him like a lamb sacrificed for Aid el-Kebir" (Ben Jelloun, 2009). Nicoletta Pireddu states that:

The evolution of Azel's state of mind and personal life is symptomatic of the profound trauma generated by the cleavage between what we may call the migrant's pleasure principle - the easy Europeanization of his dreams - and the reality principle - the concrete social, political, and administrative mechanisms of Euromediterranean relations and of European immigration, laying bare the antinomies of the notion of community and challenging idealized perspectives on hospitality. They are doomed to exclusion on both shores, simultaneously as the hospes, the upsetting stranger demanding hospitality, and the hostis, the enemy, both on the European territory and back to their own homeland. (Pireddu, 2009)

Azel's traumatizing European adventure, along with many characters in the novel, proves the painful truth of Moha's oracle. in the novel, the migrants' experiences such as despair, discrimination, identity crisis, inner conflicts, and alienation are significantly uttered by Moha, an eccentric figure of the madman-philosopher. in Leaving Tangier, almost all characters yearn for leaping to the other side of the Mediterranean for improving life, except for Moha. Although he realizes the wrong applications and traumatic positions in his country, Moha criticizes the young Moroccans who are leaving their country easily in order to get better chances in Europe. Pireddu asserts that "haunted by death, Moha deprecates the Moroccans' facile idealization of departure as the sole remedy for their destitution, and attacks the mirage of Europe and its ideology of discrimination" (Pireddu, 2009). Moha complains that "Leaving! Leaving! Leaving any way at all, at any cost, drowning, floating on the water, belly bloated, face eaten away by the salt, eyes gone. Leaving! That's all you have come up with for a solution"(Ben Jelloun, 2009). Moha's denouncement presents Europe's incongruous policies toward the immigrants. His speech also includes many warnings to the young natives who choose leaving the homeland as an easy solution: This is how Moha puts the painful reality that the native Moroccans will encounter in Europe:

[you] want to take off, leave, quit the country, move in with the Europeans, but they are not expecting you, or rather, they are: with dogs, German Shepherds, handcuffs, a kick in the butt, and you think that there's work over there, comfort, grace and beauty, but my poor friends, there is sadness, loneliness, all shades of gray and money as well, but not for those who come without invitation! Right, you know what l'm talking about: how many guys left and wound up drowned? How many left and got sent back? How many dissolved into thin air and we don't even know if they still exist, their families haven't had any news of them, but me, I know where they are: they are here, in my jebella hood, all piled on top of one another, lying low like thieves, waiting for the light in order to emerge, and that's not a life. (Ben Jelloun, 2009)

Moha's painful voice "brings back to the foreground the sacredness of Africa's geographical and cultural roots as the main source of safety and redemption" (Pireddu, 2009). He says: "I'm heading for Africa, land of our ancestors, vast Africa, where people have time to take a look at life even if life isn't generous to them" (Ben Jelloun, 2009). Moha clearly expresses the agonizing situation of Africa and its people that have been subjugated and degraded for years by the colonizer countries: "Africa, cursed by heavens, Africa pillaged by Blacks wearing ties, by Whites wearing ties, by monkeys in tuxedos, even by people who are sometimes completely invisible, but Africans know this, they don't wait to be told what's going on." (Ben Jelloun, 2009). Racism and racist attitudes are inseparable parts in the history of colonialism. Moha points out that skin color and physical differences provide superiority or inferiority to people. He criticizes his people for behaving like the superior races toward the black Africans. Accordingly, what brings the white Arabs and Europeans together is the issue of racism for which he is anxious. Moha criticizes that: 
ISSN 2411-9563 (Print) ISSN 2312-8429 (Online)
European Journal of Social Sciences Education and Research
September-December 2014

Volume 1, Issue 2

the Africans losing just a bit more of their souls, while we white Arabs (well, let's say brown or olive or cinnamon skinned), we feel superior, stupidly despise, with a racism that needed to get some exercise, but when the poor Africans with black skin, we lose our control, we feel justified in looking down on them, we act like certain European politicians, looking down on you when in fact that don't even see you. (Ben Jelloun, 2009)

The novel ends with a part, entitled "Returning" which describes the imagery returning of immigrant characters to their homeland in a dreamy atmosphere, including some mythical allusions. in the last part, not only the novel characters such as Kenza, Azel, Flaubert, Moha, Soumaya, and Miguel, but also some literary figures such as Don Quixote, Emilzola, a librarian in Douala, and M. Panza appear. The author gathers all these characters in a boat, named Toutia, which is mentioned in the first pages of the novel. These characters, who are on Toutia, are the ones that have not found a suitable place either in their Moroccan homeland or in their adoptive home. The ambivalent nature of Toutia is stated by the narrator: "this boat seems both familiar and strange to me" (Ben Jelloun, 2009). Toutia is "a kind of fatal mediator between the two shores" (Pireddu, 2009) that is carrying away the would-be Europeans from their dream land as Europe's "others" to their own roots. Embarking on Toutia, passengers begin once again an endless journey as spectral characters. The phantoms of Leaving Tangier walk several days "to back to their roots, to their native land, a destiny that has appeared to them as a kind of command, an indisputable order [...]. This is their season, a season for no one but them, for all those who have suffered, who have not found their place in life" (Ben Jelloun, 2009). According to Pireddu, "instead of offering a free zone where exiles, refugees, and immigrants are welcome and protected in view of their future naturalization, Toutia rather generates an ironic "imagined community" (Anderson) made of all the failed and displaced dreamers of Europe, cast off as on a ship of fools without the consolation of a comeback to their own roots" (Pireddu, 2009). Ben Jelloun's symbolic returning represents the migrants' hybrid status torn between home and abroad, dream and actual reality, Africa and Europe. Pireddu explains that:

migration as is far more than a simple physical displacement from one spot to another in a geographical space. It cannot be measured in meters but rather in change indexes. It is about a rupture in a living continuity and a graft onto another living continuity. They are doomed to exclusion on both shores, simultaneously as the hospes, the upsetting stranger demanding hospitality, and the hostis, the enemy, both on the European territory and back to their own homeland. Neither fully present nor radically absent in either location. (Pireddu, 2009)

Consequently, Leaving Tangier presents that regardless of the circumstances and of the outcome of their Mediterranean crossing, migrants turn into paradoxical non-existing human beings. The novel richly includes characters who desire to leap, legally or illegally, the other side of the Mediterranean in order to attain better working and life conditions. Levy notes that the novel "compellingly analyzes postcolonial dreamers and their dreams while critiquing the underside of globalization - the internalized self-hatred that causes one to long for what one is not" (Levy, 2010).

Throughout the novel, leaving Tangier keeps the characters so busy that they actually lose both their North African and newly gained European identities. Torn between the different cultural and life conditions in their homeland and Europe, the migrant characters experience alienation, hybridity, and despair. The fulfillment of their dream comes at the cost of compromises and sacrifices that end with the protagonists' physical and emotional annihilation. Their humanity and identity turn into paradoxical non-existing human beings because of their estrangement both from their Moroccan roots and from their newly acquired Europeanism. They are condemned to invisibility by their foreignness even when they are socially and legally legitimized in Europe.

\section{REFERENCES}

[1] Ben Jelloun, Tahar. (2009). Leaving Tangier. trans., Linda Coverdale New York: Penguin Books.

[2] Ben Jelloun, Tahar and Guppy, Shusha. (Fall, 1999) "Tahar Ben Jelloun, The Art of Fiction." The Paris Review, Vol. 41, Issue 152, pp. 40-62.

[3] _ - (March 1997). "Tangier: myths and memories." in ed., Roy Malkin The Unesco Courier, pp. 10-14.

[4] _ (August-September 1991). "Interview: Tahar Ben Jelloun." in ed., Adel Rifaat The Unesco Courier, pp. 4-6.

[5] _. "A Conversation with Tahar Ben Jelloun," available on www.penguin.com/.../leaving-tangier/9780143, accessed on 10/05/2014. 
[6] Brandabur, A. Clare. (2010). "Colonialism and Orientalism: Images of Paul Bowles in Tahar Ben Jelloun and Mohamed Choukri." Paper presented at 2010 Lisbon Conference.

[7] Campbell, Neil. (2000). "Dialogic Encounters and Hybrid Routes in the Fiction, Travel Writing, and Translations of Paul Bowles." Transatlantic Studies, ed., Will Kaufman and Heidi Slettedahl Macpherson. Lanham, Md.: University Press of America, pp. 171-185.

[8] Levy, Michele. (2010). "Tahar Ben Jelloun: Leaving Tangier." World Literature Today, Vol, 84, No. 1, p. 61.

[9] Nice, Pamela. (2009). "Dreaming in Morocco." in Elie Chalala, ed., AL JADID, Vol. 15, No. 61. p. 45.

[10] Page Melvin E. \& Sonnenburg, Penny M. (2003). Colonialism: An International Social, Cultural, and Political Encyclopedia. Vol. 1 Santa Barbara, CA: ABC-Clio.

[11] Parekh, Pushpa N. \& Jagne, Siga F. (1998). Postcolonial African Writers: A Bio-Bibliographical Critical Sourcebook. Westport, CT, USA: Greenwood Press.

[12] Pireddu, Nicoletta. (Fall 2009). "A Moroccan Tale of an Outlandish Europe: Ben Jelloun's Departures for a Double Exile." Research in African Literatures, Vol. 40, No. 3, pp. 16-36. DOI: 10.1353/ral.0.0180.

[13] Walonen, Michael K. (2011). Writing Tangier in the Postcolonial Transition: Space and Power in Expatriate and North African Literature. Farnham, Surrey, England: Ashgate Pub. 